\title{
SLUDGE BATCH 4 BASELINE MELT RATE FURNACE AND SLURRY-FED MELT RATE FURNACE TESTS WITH FRITS 418 AND 510 (U)
}

M. E. Smith

T. M. Jones

D. H. Miller

September 2007

Process Science and Engineering Section Savannah River National Laboratory Aiken, SC 29808

Prepared for the U.S. Department of Energy Under Contract Number DEAC09-96SR18500

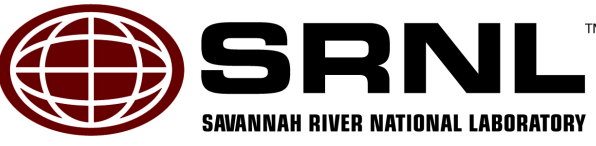

We Put Science To Work 
WSRC-STI-2007-00450

\section{DISCLAIMER}

This report was prepared by Washington Savannah River Company (WSRC) for the United States Department of Energy under Contract No. DE-AC09-96SR18500 and is an account of work performed under that contract. Neither the United States Department of Energy, nor WSRC, nor any of their employees makes any warranty, expressed or implied, or assumes any legal liability or responsibility for the accuracy, completeness, or usefulness, of any information, apparatus, or product or process disclosed herein or represents that its use will not infringe privately owned rights. Reference herein to any specific commercial product, process, or service by trademark, name, manufacturer or otherwise does not necessarily constitute or imply endorsement, recommendation, or favoring of same by WSRC or by the United States Government or any agency thereof. The views and opinions of the authors expressed herein do not necessarily state or reflect those of the United States Government or any agency thereof.

Printed in the United States of America

Prepared For

U.S. Department of Energy 
Key Words: Melt rate, SB4,

DWPF, glass

Retention: Permanent

\section{SLUDGE BATCH 4 BASELINE MELT RATE FURNACE AND SLURRY-FED MELT RATE FURNACE TESTS WITH FRITS 418 AND 510 (U)}

M. E. Smith

T. M. Jones

D. H. Miller

September 2007

Process Science and Engineering Section Savannah River National Laboratory

Aiken, SC 29808

Prepared for the U.S. Department of Energy Under Contract Number DEAC09-96SR18500

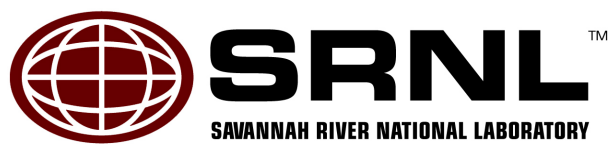

We Put Science To Work 


\section{REVIEWS AND APPROVALS}

\section{AUTHORS:}

M. E. Smith, Process Science and Engineering Section

Date

T. M. Jones, Process Science and Engineering Section

Date

D. H. Miller, Process Science and Engineering Section

Date

\section{TECHNICAL REVIEWER:}

K. M. Fox, Process Science and Engineering Section

Date

\section{APPROVERS}

R. E. Edwards, Manager, Process Science and Engineering Section

Date

C. C. Herman, Manager, Process Engineering Technology

Date

J. E. Occhipinti, Manager, Waste Solidification Engineering Date Process Cognizant Engineering 
WSRC-STI-2007-00450

\section{EXECUTIVE SUMMARY}

Several Slurry-Fed Melt Rate Furnace (SMRF) tests with earlier projections of the Sludge Batch 4 (SB4) composition have been performed. ${ }^{1,2}$ The first SB4 SMRF test used Frits 418 and 320, however it was found after the test that the REDuction/OXidation (REDOX) correlation at that time did not have the proper oxidation state for manganese. ${ }^{1}$ Because the manganese level in the SB4 sludge was higher than previous sludge batches tested, the impact of the higher manganese oxidation state was greater. The glasses were highly oxidized and very foamy, and therefore the results were inconclusive. After resolving this REDOX issue, Frits 418, 425, and 503 were tested in the SMRF with the updated baseline SB4 projection. ${ }^{2}$

Based on dry-fed Melt Rate Furnace (MRF) tests and the above mentioned SMRF tests, two previous frit recommendations were made by the Savannah River National Laboratory (SRNL) for processing of SB4 in the Defense Waste Processing Facility (DWPF). The first was Frit 503 based on the June 2006 composition projections. ${ }^{3}$ The recommendation was changed to Frit 418 as a result of the October 2006 composition projections (after the Tank 40 decant was implemented as part of the preparation plan). ${ }^{\#}$ However, the start of SB4 processing was delayed due to the control room consolidation outage and the repair of the valve box in the Tank 51 to Tank 40 transfer line. These delays resulted in changes to the projected SB4 composition. ${ }^{4}$

Due to the slight change in composition and based on preliminary dry-fed MRF testing, SRNL believed that Frit 510 would increase throughput in processing SB4 in DWPF. Frit 418, which was used in processing Sludge Batch 3 (SB3), was a viable candidate and available in DWPF. Therefore, it was used during the initial SB4 processing. Due to the potential for higher melt rates with Frit 510, SMRF tests with the latest SB4 composition (1298 canisters) and Frits 510 and 418 were performed at a targeted waste loading (WL) of 35\%. The "1298 canisters" describes the number of equivalent canisters that would be produced from the beginning of the current contract period before SB3 is blended with SB4.

The melt rate for the SMRF SB4/Frit 510 test was 14.6 grams/minute. Due to cold cap mounding problems with the SMRF SB4/Frit 418 feed at 50 weight \% solids that prevented a melt rate determination, this feed was diluted to 45 weight \% solids. The melt rate for this diluted feed was 8.9 grams/minute. A correction factor of 1.2 for estimating the melt rate at 50 weight $\%$ solids from 45 weight \% solids test results (based on previous SMRF testing ${ }^{5}$ ) was then used to estimate a melt rate of 10.7 grams/minute for SB4/Frit 418 at 50 weight \% solids. Therefore, the use of Frit 510 versus Frit 418 with SB4 resulted in a higher melt rate (14.6 versus an estimated 10.7 grams/minute). For reference, a previous SMRF test with SB3/Frit 418 feed at 35\% waste loading and 50 weight \% solids resulted in a melt rate of 14.1 grams/minute. ${ }^{5}$ Therefore, depending on the actual feed rheology, the use of Frit 510 with SB4 could result in similar melt rates as experienced with SB3/Frit 418 feed in the DWPF.

${ }^{\#}$ Frit 418 was identified as a primary candidate for the October 2006 SB4 projections. In addition, the higher $\mathrm{B}_{2} \mathrm{O}_{3}$ based frits (Frits 505, 510, and 511) were also identified as candidate frits. This information was presented to the Liquid Waste Organization and the DWPF via a presentation at the DWPF Plan of the Month meeting (see WSRC-NB-2006-00017, pages 106-118 for more detail). 


\section{TABLE OF CONTENTS}

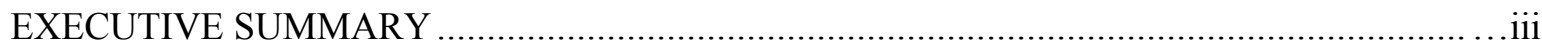

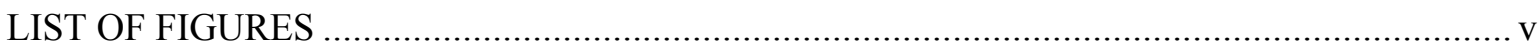

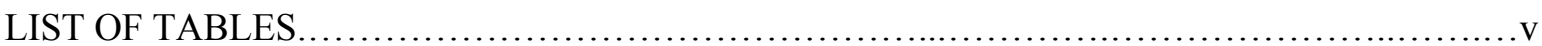

LIST OF ACRONYMS/ABBREVIATIONS ................................................................. vi

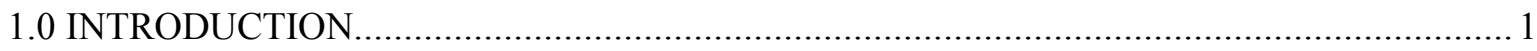

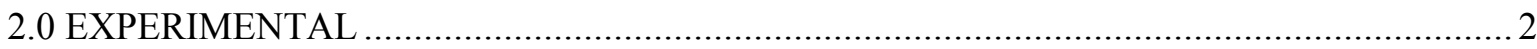

2.1 22-L SRAT/SME Feed Preparation Details for SMRF Runs..........................................2

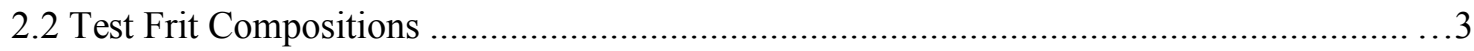

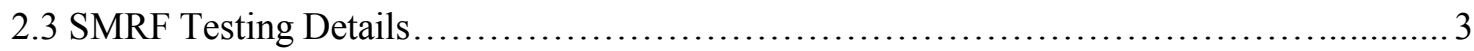

2.4 MRF Testing Details............................................................ 3

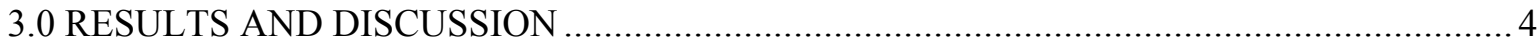

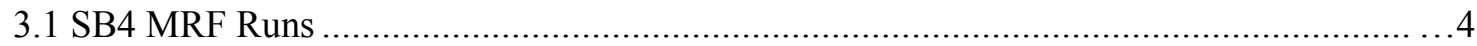

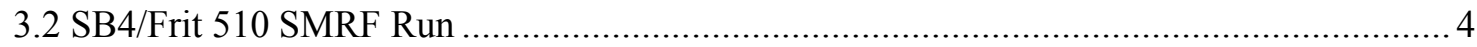

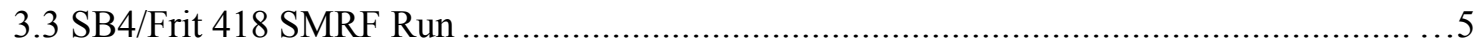

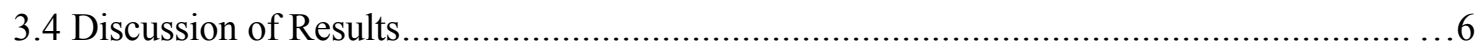

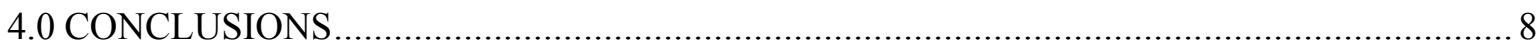

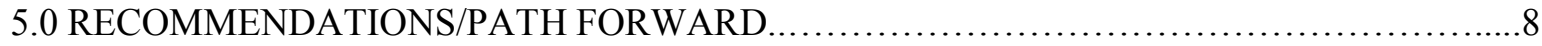

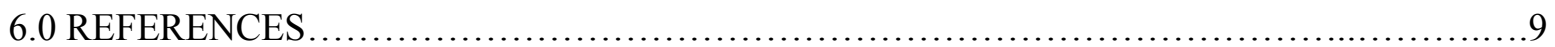

ATTACHMENT A...................................................................... 


\section{LIST OF FIGURES}

Figure 3-1. SMRF Cold Cap at 1400 on 7/11/07 during SB4/Frit 418 Test.

.5

\section{LIST OF TABLES}

Table 2-1. SB4 Sludge Simulant and Typical SB3 Simulant Sludge Compositions (Elemental Weight \% Calcined Solids)............................................................

Table 2-2. Descriptions of SRAT/SME Runs for SB4 SMRF Tests...................................

Table 2-3. Frit Compositions Used in Latest SB4 MRF and SMRF Tests (SMRF Frits in "Bold").....3

Table 3-1. SB4 MRF Test Summary and Results.......................................... 4

Table 3-2. REDOX Values of the SB4 SMRF Test Glass Samples..................................6

Table 3-3. Power (BTU/Min) Consumptions for the SB4 SMRF Runs...........................6

Table 3-4. SB4 SMRF Tests Melt Rate (Grams/Minute) Results at 35\% WL........................7 


\section{LIST OF ACRONYMS/ABBREVIATIONS}

$\begin{array}{ll}\text { ACTL } & \text { Aiken County Technology Laboratory } \\ \text { ARP } & \text { Actinide Removal Process } \\ \text { DWPF } & \text { Defense Waste Processing Facility } \\ \text { ID } & \text { Identification } \\ \text { LMR } & \text { Linear Melt Rate } \\ \text { MRF } & \text { Melt Rate Furnace } \\ \text { MST } & \text { Monosodium Titanate } \\ \text { REDOX } & \text { REDuction/OXidation } \\ \text { SB3 } & \text { Sludge Batch 3 } \\ \text { SB4 } & \text { Sludge Batch 4 } \\ \text { SME } & \text { Slurry Mix Evaporator } \\ \text { SMRF } & \text { Slurry-Fed Melt Rate Furnace } \\ \text { SRAT } & \text { Sludge Receipt and Adjustment Tank } \\ \text { SRNL } & \text { Savannah River National Laboratory } \\ \text { WL } & \text { Waste Loading } \\ \text { WSRC } & \text { Washington Savannah River Company }\end{array}$


WSRC-STI-2007-00450

\subsection{INTRODUCTION}

Several Slurry-Fed Melt Rate Furnace (SMRF) tests with earlier projections of the Sludge Batch 4 (SB4) composition have been performed. ${ }^{1,2}$ The first SB4 SMRF test used Frits 418 and 320, however it was found that the REDuction/OXidation (REDOX) correlation at that time did not have the proper oxidation state for manganese. ${ }^{1}$ Because the manganese level in the SB4 sludge was higher than previous sludge batches tested, the impact of the higher manganese oxidation state was greater. The glasses were highly oxidized and very foamy and therefore the results were inconclusive. After resolving this REDOX issue, Frits 418, 425, and 503 were tested in the SMRF with an updated baseline projection of the SB4 composition. $^{2}$

Based on dry-fed Melt Rate Furnace (MRF) tests and the above mentioned SMRF tests, two previous frit recommendations were made by the Savannah River National Laboratory (SRNL) for processing of SB4 in the Defense Waste Processing Facility (DWPF). The first was Frit 503 based on the June 2006 composition projections. ${ }^{3}$ The recommendation was changed to Frit 418 from the October 2006 composition projections (after the Tank 40 decant was implemented as part of the preparation plan). However, the start of SB4 processing was delayed due to the control room consolidation outage and the repair of the valve box in the Tank 51 to Tank 40 transfer line. These delays resulted in changes to the projected SB4 composition. ${ }^{4}$

Due to the slight change in composition and based on preliminary dry-fed MRF testing, SRNL believed that Frit 510 would increase throughput in processing SB4 in DWPF. Frit 418, which was used to process SB3, was a viable candidate and available in DWPF. Therefore it was used during the initial SB4 processing. Due to the potential for higher melt rates with Frit 510, SMRF tests with the latest SB4 composition (1298 canisters) and Frits 510 and 418 were performed at a targeted waste loading (WL) of $35 \%$. The "1298 canisters" describes the number of equivalent canisters that would be produced from the beginning of the current contract period before SB3 is blended with SB4.

The work was performed per Task Technical and Quality Assurance Plan WSRC-RP-2006-00713. ${ }^{6}$ Tests were performed with non-radioactive, simulated SB4 material. Due to the small-scale of the test equipment and the design of the equipment, as well as the use of non-radioactive simulant feed, the behavior of the actual radioactive SB4 feed in the DWPF melter cannot be fully proven. However, previous SRNL simulant melt rate results have shown trends that are consistent with those of actual melt rates obtained at the DWPF. 


\subsection{EXPERIMENTAL}

\subsection{2-L SRAT/SME Feed Preparation Details for SMRF Runs}

The SB4 sludge composition used in these melt rate tests was designated as "1298 canisters". As previously stated, "1298 canisters" describes the number of equivalent canisters that would be produced from the beginning of the current contract period before SB3 is blended with SB4. This targeted sludge did not include auxiliary waste streams such as the Actinide Removal Process (ARP) stream, which contains monosodium titanate (MST), entrained sludge, and various soluble sodium compounds as a result of filter cleaning and stream adjustment for transfer.

The Sludge Receipt and Adjustment Tank/Slurry Mix Evaporator (SRAT/SME) products were made in the Aiken County Technology Laboratory (ACTL) 22-L vessels using the above described sludge composition. The feed preparation process strategy used 135\% acid stoichiometry and targets of 35\% waste loading (WL) and 0.2 REDOX defined as $\mathrm{Fe}^{2+} / \Sigma \mathrm{Fe}$.

Table 2-1 gives the analysis of SB4 simulant used for these tests as well as the composition of the typical SB3 simulant. The main differences between the SB4 and SB3 sludge compositions are the higher levels of aluminum and the lower level of iron in the SB4 sludge. The higher aluminum and lower iron concentrations would tend to lower melt rate. The SB4 sludge identification (ID) used for these tests was 1298-1.

Table 2-1. SB4 Sludge Simulant and Typical SB3 Simulant Sludge Compositions (Elemental Weight \% Calcined Solids)

\begin{tabular}{||c|c|c||}
\hline ELEMENT & SB4 SIMULANT & $\begin{array}{c}\text { TYPICAL SB3 }^{7} \\
\text { SIMULANT }\end{array}$ \\
\hline $\mathrm{Al}$ & 16.0 & 9.57 \\
\hline $\mathrm{Ba}$ & 0.05 & 0.14 \\
\hline $\mathrm{Ca}$ & 2.47 & 2.37 \\
\hline $\mathrm{Cr}$ & 0.11 & 0.15 \\
\hline $\mathrm{Fe}$ & 21.80 & 28.35 \\
\hline $\mathrm{K}$ & 0.17 & 0.12 \\
\hline $\mathrm{Mg}$ & 1.98 & 2.15 \\
\hline $\mathrm{Mn}$ & 5.24 & 4.07 \\
\hline $\mathrm{Na}$ & 12.7 & 14.05 \\
\hline $\mathrm{Ni}$ & 1.43 & 1.06 \\
\hline $\mathrm{Pb}$ & 0 & 0.01 \\
\hline $\mathrm{Si}$ & 1.44 & 1.04 \\
\hline $\mathrm{Zn}$ & 0.04 & 0.32 \\
\hline $\mathrm{Zr}$ & 0.06 & 0.49 \\
\hline
\end{tabular}

Two SRAT/SME runs were performed to make each SMRF feed listed in Table 2-2. The SB4 SRAT/SME run ID numbers and the run plan numbers for each feed are given in Table 2-2. Compositions of the SME products for the SMRF runs are given in Appendix A. Prior to performing the SMRF tests, both SMRF feeds were pumped with the SMRF feed delivery system to ensure that they could be fed at the required 100 grams $/ 20$ second feed cycle. Both feeds met this requirement. 
WSRC-STI-2007-00450

Table 2-2. Descriptions of SRAT/SME Runs for SB4 SMRF Tests

\begin{tabular}{||c|c|c||}
\hline SRAT/SME RUN ID & FEED DESCRIPTION & *SRNL RUN PLAN \# \\
\hline SB4-73 and SB4-74 & SB4/Frit 418 (35\% waste loading) & SRNL-PSE-2007-00142 \\
\hline SB4-75 and SB4-76 & SB4/Frit 510 (35\% waste loading) & SRNL-PSE-2007-00147 \\
\hline \hline
\end{tabular}

* Additional feed preparation details for these runs are given in SRNL-PSE-2007-00197

\subsection{Test Frit Compositions}

Frits 418, 503, 509, 510, and 511 were tested in the MRF with this same SB4 composition at 35\% waste loading. Based on the tests results and other considerations, Frits 418 and 510 were selected for testing in the SMRF. Frit 418 was used to process SB3 at DWPF as well as for initial processing of SB4 and was considered the baseline frit for these tests. Table 2-3 gives the compositions of these frits.

Table 2-3. Frits Compositions Used in Latest SB4 MRF and SMRF Tests (SMRF Frits in "Bold")

\begin{tabular}{||c|c|c|c|c||}
\hline FRIT & $\mathrm{B}_{2} \mathrm{O}_{3}$ & $\mathrm{Li}_{2} \mathrm{O}$ & $\mathrm{Na}_{2} \mathrm{O}$ & $\mathrm{SiO}_{2}$ \\
\hline $\mathbf{4 1 8}$ & 8 & 8 & 8 & 76 \\
\hline $\mathbf{5 1 0}$ & 14 & 8 & 8 & 70 \\
\hline 503 & 14 & 8 & 4 & 74 \\
\hline 509 & 14 & 8 & 7 & 71 \\
\hline 511 & 14 & 8 & 9 & 69 \\
\hline
\end{tabular}

\subsection{SMRF Testing Details}

Details of the SMRF configuration and operation are documented elsewhere. ${ }^{8}$ The operational parameters for the SMRF tests were consistent with previous testing. More specifically, the melt pool and vapor space setpoints were $1125^{\circ} \mathrm{C}$ and $750^{\circ} \mathrm{C}$, respectively. The duration for each feed cycle after the vapor space had reached the feed initiation setpoint of $750^{\circ} \mathrm{C}$ was 20 seconds. The measured current for the melt pool and vapor space heaters were both about 20 amps for the two tests.

\subsection{MRF Testing Details}

The dry-fed MRF has a cylindrical inner chamber that is approximately 0.5 cubic feet in size, with heating coils winding around the chamber walls. The diameter of the chamber is $\sim 7$ ", and an insulating sleeve and $1200 \mathrm{~mL}$ stainless steel beaker (6" deep) were inserted from the top for each test. The tests were conducted with the stainless steel beakers inserted with the sleeve so that the beaker bottom was approximately flush with the top of the uppermost chamber coil. An insulating block was used to cover the beaker. The furnace was heated to $1150^{\circ} \mathrm{C}$ with the top opening covered. Once the furnace reached the setpoint, the cover was removed and a beaker containing sufficient dried, sieved material to produce 525 grams of glass was inserted. After 50 minutes, the beaker was removed from the furnace and allowed to cool to room temperature. This residence time in the furnace was established as a standard test time for melt rate comparison for this dry-fed furnace. ${ }^{9}$ For these MRF tests, relative melt rate was determined by measuring the height of the glass layer in the bottom of each sectioned beaker at 0.25 " intervals. A new technique using digital radiography to view the glass layer height was not used for these MRF tests due to equipment problems. The average height of the glass layer and residence time in the furnace was used to yield a relative linear melt rate (LMR) number (inches/hour). General observations of the beakers can also be used to describe differences between runs. 
WSRC-STI-2007-00450

\subsection{RESULTS AND DISCUSSION}

As previously discussed, several SB4 MRF runs were performed with a set of candidate frits. Based on the results of these runs, two SMRF runs were performed with SB4 simulated sludge with Frits 418 and 510 at 35\% WL. The SMRF runs were recorded in notebook WSRC-NB-2004-00123 and performed per Run Plan SRNL-PSE-2007-00114.

\subsection{SB4 MRF Runs}

Table 3-1 summarizes the results of the SB4 MRF runs performed in 2007. All melt rates are given in LMR. For comparison, the melt rate previously measured for SB3/Frit 418 (35\% WL) was 0.51 inches $/ \mathrm{hr} .{ }^{10}$ However, a shift in the melt rate of the standard used does not allow comparison with these results and the previous SB3/Frit $418 \mathrm{MRF}$ result. The frits that indicated a possible positive impact on SB4 melt rate were Frits 510 and 511.

Table 3-1. SB4 MRF Test Summary and Results

\begin{tabular}{||c|c|c||}
\hline FRIT ID & WL & *LMR (IN/HR) \\
\hline 418 & 35 & 0.69 \\
\hline 503 & 35 & 0.65 \\
\hline 509 & 35 & 0.69 \\
\hline 510 & 35 & 0.71 \\
\hline 511 & 35 & 0.77 \\
\hline$-\cdot----\cdot--$ & ------ & $-\cdot-\cdot-----$ \\
\hline 510 & 35 & 0.71 \\
\hline 510 & 38 & 0.66 \\
\hline 510 & 41 & 0.53 \\
\hline
\end{tabular}

* Based on historical MRF data, the estimated precision in LMR is about +/- 0.02 inches/hour

SRNL made the test frits for the MRF runs because the amount of test frit needed for each MRF run was small (less than 100 grams). The frits for the SMRF tests (418 and 510), on the other hand, were taken from existing lots at DWPF. Based on the promising SB4/Frit 511 MRF result, it would appear that Frit 511 would be the logical frit to be recommended for SB4. However, the nominal stage assessment for Frit 512, when coupled with the baseline SB4 composition, indicated a projected operating window of only $25-38 \%$ WL (being low viscosity limited). This is a 3 point decrease in the upper percent WL limit for Frit 512 relative to the projected operating window from Frit 510's assessment. Frit 511 is very similar to Frit 512 (Frit 512 contains only $1 \%$ more $\mathrm{Na}_{2} \mathrm{O}$ and $1 \%$ less $\mathrm{SiO}_{2}$ ). Due to its relatively poor projected operational window, no SB4 "1298 canister" MRF tests were performed with Frit 512. Because of this compositional similarity between Frits 511 and 512, the use of Frit 511 presents concerns of negative impacts on property predictions due to compositional variation at the upper end of DWPF's projected WL operating window. Therefore, Frit 511 was not considered for SB4 SMRF testing. Additional details concerning this decision are documented elsewhere. ${ }^{4}$

\subsection{SB4/Frit 510 SMRF Run}

The SMRF was charged with $6.1 \mathrm{~kg}$ of glass (drained from the SMRF after the SB4/Frit 503 (35\% WL) $5 / 26 / 06$ test) and heated up to operating temperatures on 7/9/07. Feeding of the SB4/Frit 510 feed was started at 0710 hours on 7/10/07. The feed pump speed was $250 \mathrm{rpm}$ to deliver about 100 grams of feed per each 20 second feed cycle. Feeding and pouring were continued until 1330 hours without any major feed problems or signs of overfeeding of the melter. Some cold cap mounding was observed and the cold 
cap mound under the feed tube was manually knocked down at 1330. At 1400 the pour rate was higher than what would be expected with the feed rate and therefore feeding was stopped to allow the cold cap to burn off. Feeding was restarted at 1537 . At 1720 feeding was stopped because the cold cap was very dark and a mound was up near the tip of the feed tube. The average melt rate from 1000 to 1330 hours (steady state portion of test) was 14.6 grams/minute. A total of 7262 grams of glass was poured during this test.

\subsection{SB4/Frit 418 SMRF Run}

The SB4/Frit 418 SMRF test was performed on 7/11/07 and 7/12/07. Feeding was started at 0710 hours on 7/11/07. A feed pump speed of $250 \mathrm{rpm}$ was used to deliver about 100 grams of feed per each 20 second feed cycle. Feeding and pouring were continued until 1150 hours when an inspection of the cold cap showed a complete bridging of the cold cap and the cold cap was very thick. Therefore feeding was stopped at 1155 hours but the pouring was continued. At 1300 hours the cold cap had burned off and the glass height was at the overflow level. Feeding was restarted at 1300 hours but stopped at 1400 hours due to mounding of the cold cap (see Figure 3-1). The left side of the melt pool was uncovered, but the mounding indicated that the feed was too thick. In addition, it was noted that the feed rate of 40 grams/minute was too high relative to the resultant pour rate of only $6-8$ grams/minute ( 40 grams $/$ minute should result in a pour rate of about 16.5 grams/minute). A total of 3800 grams of glass was poured during this part of the test. Due to excessive mounding and lack of cold cap coverage, an accurate melt rate could not be determined for SB4/Frit 418 at 50 weight $\%$ solids. A decision was made to dilute the feed from 49.5 to 45 weight \% solids to improve the rheology of the feed to allow for better cold cap coverage. Therefore 101 grams of water was added per $1 \mathrm{~kg}$ of feed. This decision was made even though the SB4/Frit 510 feed was only tested at 50 weight \% solids. Previous SMRF tests with SB3/Frit 418 had determined a correction factor of 1.2 to estimate a melt rate at 50 weight $\%$ solids from tests using 45 weight $\%$ solids feed. ${ }^{5}$ Part of the rationale for the dilution decision was that there was not enough feed left to allow for any more mounding problems.

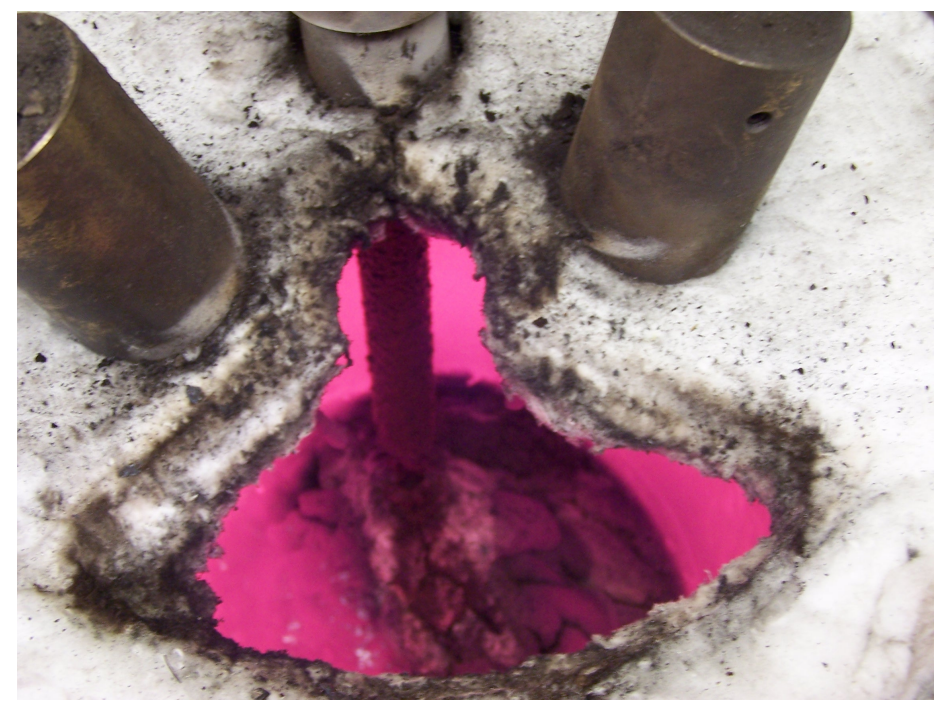

Figure 3-1. SMRF Cold Cap at 1400 on 7/11/07 during SB4/Frit 418 Test

Feeding was restarted at 1438 hours with the diluted feed. However, at 1600 hours a power outage stopped the test as the pour and drain induction heaters could not be restarted (possibly due to power supply tuning problems). It was decided to restart the test the next day. For information, 810 grams of glass was poured after the dilution of the feed so that a total of 4610 grams was poured on 7/11/07. 
The test was resumed on 7/12/07 at 0710 with the diluted feed. At 1230 hours, the entire melt surface was covered with a cold cap, but the cold cap was orange with no major dark areas, thus indicating a thin cold cap. Just 15 minutes later the cold cap was observed to be turning slightly darker than that observed at 1230 hours. At 1255 hours, the test had to be stopped because there was not enough feed left to continue the test. The average melt rate from 0800 to 1230 hours (steady state portion of test) was 8.9 grams/minute. With the previously mentioned correction factor of 1.2, an estimated melt rate of about 10.7 grams/minute would have been achieved at 50 weight \% solids if the feed had flowed better on the melt pool/cold cap. A total of 3332 grams of glass was poured. At 1330 hours the drain induction heater was started and draining began at 1415 hours. Draining was completed at 1538 hours and about 5000 grams of glass was drained.

\subsection{Discussion of Results}

Glass pour samples were taken at the end of each SMRF test. In addition, a glass drain sample was taken at the end of the SB4/Frit 418 test drain. The compositions of these three glass samples are given in Attachment A (Table A-4). Table 3-2 summarizes the REDOX values of the three glass samples. The $\mathrm{Fe}^{2+} / \Sigma \mathrm{Fe}$ target was 0.20 . SME product analyses projected a value $>0.15 .{ }^{11}$ The actual measured values of the glass samples were slightly higher than the SME product projections, but close to the target of 0.20.

Table 3-2. REDOX Values of the SB4 SMRF Test Glass Samples

\begin{tabular}{||c|c|c|c||}
\hline SAMPLE ID & DESCRIPTION & $\begin{array}{c}\text { GRAMS POURED/ } \\
\text { DRAINED }\end{array}$ & $\begin{array}{c}\text { *REDOX } \\
\left(\mathrm{Fe}^{2+} / \Sigma \mathrm{Fe}\right)\end{array}$ \\
\hline SMRF-0230 & End of SB4/Frit 510 pouring & 7262 & 0.200 \\
\hline SMRF-0231 & End of SB4/Frit 418 pouring & 4610 & 0.216 \\
\hline SMRF-0232 & End of SB4/Frit 418 draining & 5000 & 0.225 \\
\hline
\end{tabular}

*Average of two measurements from one sample

Another set of important parameters that was reviewed was the power consumption (BTU/min) of the plenum and melt pool heaters during these tests. Table 3-3 gives these values for the two SB4 SMRF tests as well as the power consumed in a previous SB3/Frit 418 (45\% solids) SMRF test (actual power consumptions for the SB3/Frit 418 tests documented in later SB4 melt rate report ${ }^{2}$ ). The only difference is the lower SB4/Frit 418 plenum power consumption for the 50 weight $\%$ solids run. This indicates that the cold cap was not fully covered, and therefore, less plenum power was required. When the feed was diluted to 45 weight \% solids, the cold cap flowed better and its coverage was greater, resulting in higher plenum power consumption as the contribution of heat from the melt pool to the plenum was less.

Table 3-3. Power (BTU/Min) Consumptions for the SB4 SMRF Runs

\begin{tabular}{||c|c|c|c||}
\hline & SB4/FRIT 418 & SB4/FRIT 510 & SB3/FRIT 418 \\
\hline Plenum Power & $* 85.2 / * * 94.2$ & $* 96.3$ & $* * 97.6$ \\
\hline Melt Pool Power & $* 45.8 / * * 44.4$ & $* 46.2$ & $* * 45.4$ \\
\hline
\end{tabular}

A summary of the SB4 SMRF melt rate results is given in Table 3-4. The melt rates for the SB4/Frit 510 feed at 50 weight $\%$ solids and the estimate for 50 weight \% solids SB4/Frit 418 feed were 14.6 grams/minute and 10.7 grams/minute, respectively, at $35 \%$ waste loading. For reference, a previous SMRF test with SB3/Frit 418 feed at 35\% waste loading and 50 weight $\%$ solids resulted in a melt rate of 14.1 grams/minute. ${ }^{5}$ Therefore, depending on the actual feed rheology, the use of Frit 510 with SB4 could result in similar melt rates as experienced with SB3/Frit 418 feed. 
WSRC-STI-2007-00450

Table 3-4. SB4 SMRF Tests Melt Rate (Grams/Minute) Results at 35\% WL

\begin{tabular}{|c|c|c|}
\hline \hline & $\begin{array}{c}\text { SB4/FRIT 510 } \\
(50 \mathrm{WT} \%)\end{array}$ & $\begin{array}{c}\text { SB4/FRIT 418 } \\
(45 / 50 \mathrm{WT} \%)\end{array}$ \\
\hline Melt Rate (grams/minute) & 14.6 & $8.9 / * 10.7$ \\
\hline
\end{tabular}

* This is the estimated melt rate for SB4/Frit 418 at 50 weight \% solids using a correction factor of 1.2 with the actual SB4/Frit 418 melt rate at 45 weight $\%$ solids 
WSRC-STI-2007-00450

\subsection{CONCLUSIONS}

The following conclusions can be made with regard to the latest baseline SB4 composition (designated "1298 canisters") MRF and SMRF melt rate tests with Frits 418 and 510:

- MRF tests indicated that Frits 509, 510, and 511 resulted in higher melt rates with SB4 feed than Frit 418. These frits have higher $\mathrm{B}_{2} \mathrm{O}_{3}$ and similar $\mathrm{Na}_{2} \mathrm{O}$ concentrations as compared with Frit 418 .

- Based on the promising SB4/Frit 511 MRF result, it would appear that Frit 511 would be the logical frit to be recommended for SB4. However, the nominal stage assessment for Frit 512, when coupled with the baseline SB4 composition, indicated a projected operating window of only $25-38 \%$ WL (being low viscosity limited). This is a 3 point decrease in the upper percent WL limit for Frit 512 relative to the projected operating window from Frit 510's assessment. Frit 511 is very similar to Frit 512 (Frit 512 contains only $1 \%$ more $\mathrm{Na}_{2} \mathrm{O}$ and $1 \%$ less $\mathrm{SiO}_{2}$ ). Due to its relatively poor projected operational window, no SB4 "1298 canister" MRF tests were performed with Frit 512. Because of this compositional similarity between Frits 511 and 512, the use of Frit 511 presents concerns of negative impacts on property predictions due to compositional variation at the upper end of DWPF's projected WL operating window. Therefore, Frit 511 was not considered for SB4 SMRF testing. Additional details concerning this decision are documented elsewhere. ${ }^{4}$

- The melt rate for the SMRF SB4/Frit 510 (35\% waste loading and 50 weight \% solids) test was 14.6 grams/minute. Due to cold cap mounding problems with the SMRF SB4/Frit 418 feed at 50 weight $\%$ solids that prevented a melt rate determination, this feed was diluted to 45 weight $\%$ solids. The melt rate for this diluted feed was 8.9 grams/minute. A correction factor of 1.2 was applied to allow an estimation of the melt rate at 50 weight $\%$ solids based on the 45 weight $\%$ SMRF feed tests. Therefore, the estimated melt rate for SB4/Frit 418 (35\% waste loading and 50 weight \% solids) is 10.7 grams/minute. ${ }^{5}$

- The use of Frit 510 in place of Frit 418 with SB4 resulted in a higher SMRF melt rate.

- For reference, a previous SMRF test with SB3/Frit 418 feed at 35\% waste loading and 50 weight $\%$ solids resulted in a melt rate of 14.1 grams/minute. ${ }^{5}$ Therefore, depending on the actual sludge rheology, the use of Frit 510 with SB4 could result in similar melt rates as experienced with SB3/Frit 418 feed in the DWPF.

\subsection{RECOMMENDATIONS/PATH FORWARD}

- Based on the latest results of the SB4 MRF and SMRF testing, SRNL supports its previous recommendation to use Frit 510 in processing SB4 to increase waste throughput. 
WSRC-STI-2007-00450

\subsection{REFERENCES}

1. M. E. Smith, et al. SB4 SMRF Runs with Frits 418 and 320, WSRC-TR-2005-00569, Washington Savannah River Company, December 2005, Aiken, South Carolina.

2. M. E. Smith, et al. Sludge Batch 4 Melt Rate Furnace and Slurry-Fed Melt Rate Furnace Tests with Frits 418, 425, and 503, WSRC-STI-2006-00015, June 2006, Washington Savannah River Company, Aiken, South Carolina.

3. D. K. Peeler, T. B. Edwards, and K. M. Fox. Frit Recommendation for SB4, SRNL-PSE-200600128, June 23, 2006, Washington Savannah River Company, Aiken, South Carolina.

4. D. K. Peeler, T. B. Edwards, and K. M. Fox. Delaying the SB4 Transfer: An Assessment of the Impact on the Frit Recommendation and the Variability Study, SRNL-PSE-2007-00066, March 20, 2007, Washington Savannah River Company, Aiken, South Carolina.

5. M. E. Smith, D. H. Miller, and T. H. Lorier. The Impact of Feed Preparation Acid Stoichiometry and REDOX on Melt Rate for the SB3-Frit 418 Feed System, WSRC-TR-2004-00350, July 2004, Westinghouse Savannah River Company, Aiken, South Carolina.

6. M. E. Smith and D. K. Peeler. Task Technical and Quality Assurance Plan: Investigation to Increase Overall Waste Throughput in the DWPF Melter, WSRC-RP-2004-00713, November 2004, Westinghouse Savannah River Company, Aiken, South Carolina.

7. D. H. Miller, M. E. Smith, and T. L. Lorier. The Impact of Frit 202 on Melt Rate for the SB3 Feed System, WSRC-TR-2004-00453, August 2004, Westinghouse Savannah River Company, Aiken, South Carolina.

8. M. E. Smith, D. H. Miller, and T. M. Jones. SMRF and MRF DWPF Melt Rate Testing for SB2/SB3 (Case 6b - 250 Canisters), WSRC-TR-2003-00466, October 2003, Westinghouse Savannah River Company, Aiken, South Carolina.

9. T. H. Lorier, T. M. Jones, and D. C. Witt. Melt Rate Testing for the DWPF: Summary of FY02 Testing, WSRC-TR-2002-00545, November 2002, Westinghouse Savannah River Company, Aiken, South Carolina.

10. M. E. Smith and D. H. Miller. Initial SB4 Melt Rate Furnace Testing, WSRC-TR-2005-00339, July 2005, Westinghouse Savannah River Company, Aiken, South Carolina.

11. M. S. Stone. Feed Preparation for SB4 Melt Rate Tests of Frit 510 versus Frit 418, SRNL-PSE2007-00197, September 6, 2007, Washington Savannah River Company, Aiken, South Carolina. 


\section{ATTACHMENT A \\ COMPOSITION ANALYSES OF THE SME PRODUCTS AND GLASS SAMPLES FOR THE SMRF SB4 TESTS}


Table A-1. Composition of SME Product SB4-73 for SB4/Frit 418 SMRF Tests

\section{Process Science Analytical Laboratory}

\section{Customer: Mike Stone}

Date: $7 / 12 / 07$

Sample ID: $07-S B 4-1381$

SB4-73

Lab ID: 07-2322

Sample Preparation: Li2BO4/LiNO3 and Na2O2/NaOH fusions

\section{Sample ID Lab ID}

\section{elemental wt\%-calcined}

07-SB4-1381 (A) 07-2322

07-SB4-1381 (B) 07-2322

$\begin{array}{cc}\underline{\mathrm{Al}} & \underline{\mathrm{B}} \\ \mathbf{5 . 5 4} & \mathbf{1 . 3 2} \\ \mathbf{5 . 5 2} & 1.30\end{array}$

$\underline{\mathrm{Ba}}$

0.023

0.024

$\frac{\mathrm{Ca}}{1.00}$

$\underline{\mathrm{Ce}} \quad \frac{\mathrm{Cr}}{\mathrm{F}} \quad \frac{\mathrm{Fe}}{7.65}$

$\begin{array}{lll}0.068 & 0.043 & 7.65 \\ 0.070 & 0.042 & 7.49\end{array}$

$\frac{\mathrm{K}}{0.104}$

$\frac{\mathrm{Li}}{225}$

$\underline{M g} \quad \underline{M n} \quad \underline{\mathrm{Na}} \quad \frac{\mathrm{Ni}}{\underline{\mathrm{S}}} \quad \underline{\mathrm{Si}} \quad \underline{\mathrm{Ti}} \quad \underline{\mathrm{Zn}} \quad \underline{\mathrm{Zr}}$

0.112

2.25

$\begin{array}{lllllllll}0.57 & 1.78 & 8.96 & 0.398 & 0.1 & 23.7 & 0.044 & 0.023 & 0.106\end{array}$

1.11

$\underline{\mathrm{CeO} 2} \underline{\mathrm{Cr} 2 \mathrm{O} 3} \underline{\mathrm{Fe} 2 \mathrm{O} 3}$

$\underline{\mathrm{K} 2 \mathrm{O}}$

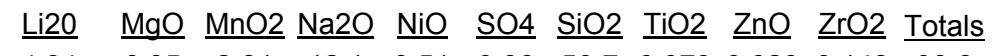
$\begin{array}{lllllllllllll}4.84 & 0.95 & 2.81 & 12.1 & 0.51 & 0.30 & 50.7 & 0.073 & 0.029 & 0.143 & 99.8\end{array}$

07-SB4-1381 (A) 07-2322

07-SB4-1381 (B) 07-2322

$\frac{\mathrm{B} 2 \mathrm{O} 3}{10.5}$

$\underline{\mathrm{BaO}}$

$\frac{\mathrm{CaO}}{1.40}$

$\begin{array}{llll}0.084 & 0.063 & 10.9 & 0.125\end{array}$

$\begin{array}{llll}0.086 & 0.061 & 10.7 & 0.134\end{array}$

4.84 $\begin{array}{llllllllllll}0.96 & 2.78 & 12.3 & 0.50 & 0.30 & 51.1 & 0.073 & 0.024 & 0.139 & 100.3\end{array}$

0.027

\section{anions (mg/Kg)}

07-SB4-1381 (A) 07-2322

07-SB4-1381 (B) 07-2322

F $\quad \underline{\mathrm{NO2}}$

$\frac{\mathrm{NO} 2}{<100}$

$\mathrm{HCO} 2$

$\underline{\mathrm{SO}} \quad \underline{\mathrm{PO}} \quad \underline{\mathrm{Cl}}$

$\frac{\mathrm{NO} 3}{22800}$

$\underline{\mathrm{HCO} 2}$

22700

52000

$\begin{array}{lll}539 & <100 & 171 \\ 538 & <100 & 170\end{array}$

Weight \% Solids Calculations

Empty Jrucible Wt :Jrucible Wt +

\begin{tabular}{|l|l|l|}
\hline Insoluble & Cruc Wt+ & Wt \% \\
\hline
\end{tabular}

\begin{tabular}{|c|c|c|c|c|c|c|c|c|c|}
\hline \multirow[b]{2}{*}{ Sample } & & & \multirow[b]{2}{*}{ Calcined } & \multirow[b]{2}{*}{ Calcined } \\
\hline & Crucible w & tWet Sample & Dry wt & Tot Solids & Wet Wt & Dry Wt & Solids & & \\
\hline $34-1381$ (A) 07-2322 & 45.4854 & 50.9935 & 48.2580 & $50.3 \%$ & 5.5081 & 2.773 & $40.3 \%$ & 47.7814 & $41.7 \%$ \\
\hline 07-SB4-1381 (B) 07-2322 & 44.3198 & 49.8290 & 47.0943 & $50.4 \%$ & 5.5092 & 2.775 & $40.3 \%$ & 46.6190 & $41.7 \%$ \\
\hline
\end{tabular}


Table A-2. Composition of SME Product SB4-74 for SB4/Frit 418 SMRF Tests

Process Science Analytical Laboratory

Customer: Mike Stone

Date: $7 / 12 / 07$

Sample ID: 07-SB4-1383

SB4-74

Lab ID: 07-2324

Sample Preparation: Li2BO4/LiNO3 and $\mathrm{Na2O} / \mathrm{NaOH}$ fusions

Sample ID Lab ID

\begin{tabular}{|c|c|c|c|c|c|c|c|c|c|c|c|c|c|c|c|c|c|c|c|}
\hline elemental wt\%-calcined & $\underline{\text { Al }}$ & B & $\underline{\mathrm{Ba}}$ & $\underline{\mathrm{Ca}}$ & $\underline{\mathrm{Cd}}$ & $\underline{\mathrm{Ce}}$ & $\underline{\mathrm{Cr}}$ & $\underline{\mathrm{Fe}}$ & $\underline{\mathbf{K}}$ & $\underline{\text { Li }}$ & $\underline{\mathrm{Mg}}$ & $\underline{\mathrm{Mn}}$ & $\underline{\mathrm{Na}}$ & $\underline{\mathrm{Ni}}$ & $\underline{\mathbf{S}}$ & $\underline{\text { Si }}$ & $\underline{\mathrm{Ti}}$ & $\underline{\mathrm{Zn}}$ & $\underline{\mathrm{Zr}}$ \\
\hline $07-S B 4-1383$ (A) 07-2324 & 5.74 & 1.30 & $0 . \overline{023}$ & $\overline{1.19}$ & $<0.010$ & 0.068 & $0 . \overline{041}$ & 7.68 & 0.107 & 2.27 & 0.540 & $\overline{1.77}$ & 9.05 & 0.37 & 0.1 & 23.7 & 0.045 & 0.017 & 0.106 \\
\hline 07-SB4-1383 (B) 07-2324 & 5.55 & 1.34 & 0.023 & 1.04 & $<0.010$ & 0.069 & 0.042 & 7.81 & 0.104 & 2.24 & 0.546 & 1.81 & 8.68 & 0.39 & 0.104 & 23.6 & 0.046 & 0.017 & 0.106 \\
\hline oxide wt\% - calcined & $\underline{\mathrm{Al} 2 \mathrm{O} 3}$ & $\underline{\mathrm{B} 2 \mathrm{O} 3}$ & $\underline{\mathrm{BaO}}$ & $\underline{\mathrm{CaO}}$ & $\underline{\mathrm{CdO}}$ & $\underline{\mathrm{CeO} 2}$ & $\underline{\mathrm{Cr} 2 \mathrm{O} 3}$ & $\underline{\mathrm{Fe} 2 \mathrm{O} 3}$ & $\underline{\mathrm{K} 2 \mathrm{O}}$ & $\underline{\mathrm{Li} 20}$ & $\underline{\mathrm{MgO}}$ & $\underline{\mathrm{MnO} 2}$ & $\underline{\mathrm{Na} 2 \mathrm{O}}$ & $\underline{\mathrm{NiO}}$ & $\underline{\mathrm{SO} 4}$ & $\underline{\mathrm{SiO} 2}$ & $\underline{\mathrm{TiO} 2}$ & $\underline{\mathrm{ZnO}}$ & $\underline{\mathrm{ZrO} 2} \underline{\text { Totals }}$ \\
\hline 07-SB4-1383 (A) 07-2324 & 10.8 & 4.19 & 0.026 & 1.67 & 0.00 & 0.084 & 0.060 & 11.0 & 0.128 & 4.88 & 0.896 & 2.80 & 12.2 & 0.47 & 0.30 & 50.7 & 0.075 & 0.021 & 0.143100 .5 \\
\hline 07-SB4-1383 (B) 07-2324 & 10.5 & 4.31 & 0.026 & 1.46 & 0.00 & 0.085 & 0.061 & 11.2 & 0.125 & 4.82 & 0.906 & 2.86 & 11.7 & 0.50 & 0.31 & 50.5 & 0.077 & 0.021 & 0.14399 .6 \\
\hline anions $(\mathrm{mg} / \mathrm{Kg})$ & $\underline{\mathbf{F}}$ & NO2 & $\underline{\mathrm{NO} 3}$ & $\underline{\mathrm{HCO} 2}$ & $\underline{\mathrm{SO} 4}$ & PO4 & $\underline{\mathrm{Cl}}$ & & & & & & & & & & & & \\
\hline 07-SB4-1383 (A) 07-2324 & $<100$ & $<100$ & 22000 & $\overline{50800}$ & $\overline{532}$ & $<100$ & $\overline{137}$ & & & & & & & & & & & & \\
\hline 07-SB4-1383 (B) 07-2324 & $<100$ & $<100$ & 22200 & 50800 & 568 & $<100$ & 142 & & & & & & & & & & & & \\
\hline
\end{tabular}

Weight \% Solids Calculations

Empty Crucible Wt Crucible Wt $+\quad$ Insoluble Cruc Wt+ Wt \%

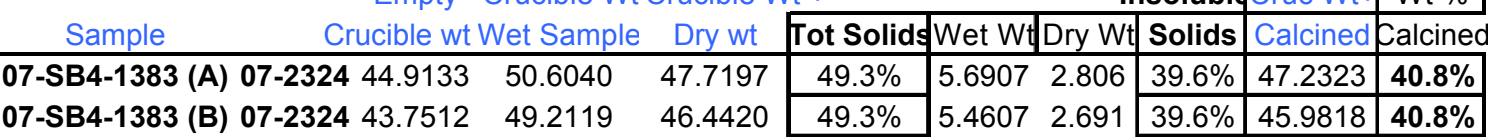


Table A-3. Composition of SME Products SB4-75 and SB4-76 for SB4/Frit 510 SMRF Tests

Process Science Analytical Laboratory

Customer: Mike Stone

Date: 9/04/07

Sample ID: 07-SB4-1402, 07-SB4-1404

07-SB4-1402 (SB4-75)

07-SB4-1404 (SB4-76)

Lab ID: 07-3008, 07-3009

Sample Preparation: $\mathrm{Li} 2 \mathrm{BO} 4 / \mathrm{LiNO} 3$ and $\mathrm{Na} 2 \mathrm{O} 2 / \mathrm{NaOH}$ fusions

Sample ID Lab ID Btcined

07-SB4-1402 (A) 07-3008

07-SB4-1402 (B) 07-3008

07-SB4-1404 (A) 07-3009

07-SB4-1404 (B) $\quad 07-3009 \quad 5.34$

\section{$\begin{array}{ll}\text { B } & \text { Ba } \\ 2.59 & 0.045\end{array}$}

0.046

0.045

$0.045 \quad 0.830$

0.830

$\begin{array}{llll}\stackrel{\mathrm{Cd}}{\mathrm{Cr}} & \underline{\mathrm{Fe}} & \underline{\mathrm{K}} \\ <0.010 & 0.039 & 7.63 & 0.181 \\ <0.010 & 0.039 & 7.60 & 0.180 \\ <0.010 & 0.039 & 7.37 & 0.195 \\ <0.010 & 0.044 & 7.46 & 0.207\end{array}$

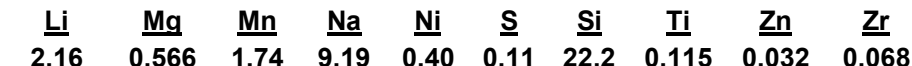
$\begin{array}{lllllllllll}2.17 & 0.565 & 1.76 & 9.00 & 0.41 & 0.10 & 22.4 & 0.115 & 0.024 & 0.067\end{array}$
$\begin{array}{lllllllllll}2.17 & 0.576 & 1.78 & 9.22 & 0.40 & 0.10 & 22.3 & 0.139 & 0.024 & 0.065\end{array}$
$\begin{array}{lllllllllll}2.16 & 0.596 & 1.76 & 9.29 & 0.41 & 0.10 & 22.0 & 0.141 & 0.025 & 0.067\end{array}$

$\begin{array}{llll}0.010 & 0.044 & 7.46 & 0.207\end{array}$

\begin{tabular}{|c|c|c|c|c|c|c|c|c|c|c|c|c|c|c|c|c|c|c|c|c|}
\hline oxide wt\% - calcine & & $\underline{\mathrm{Al} 2 \mathrm{O} 3}$ & $\mathrm{~B} 2 \mathrm{O} 3$ & $\underline{\mathrm{BaO}}$ & $\underline{\mathrm{CaO}}$ & $\underline{\mathrm{CdO}}$ & $\underline{\mathrm{Cr} 2 \mathrm{O} 3}$ & $\mathrm{Fe} 2 \mathrm{O} 3$ & $\underline{\mathrm{K} 2 \mathrm{O}}$ & $\underline{\mathrm{Li} 20}$ & $\underline{\mathrm{MgO}}$ & $\underline{\mathrm{MnO} 2}$ & $\underline{\mathrm{Na} 2 \mathrm{O}}$ & $\underline{\mathrm{NiO}}$ & $\underline{\mathrm{SO} 4}$ & $\underline{\mathrm{SiO} 2}$ & $\underline{\mathrm{TiO} 2}$ & $\underline{\mathrm{ZnO}}$ & $\underline{\mathrm{ZrO} 2}$ & Totals \\
\hline 07-SB4-1402 (A) & $07-3008$ & 9.92 & 8.34 & 0.050 & 1.20 & 0.00 & 0.057 & 10.9 & 0.217 & 4.64 & 0.940 & 2.75 & 12.4 & 0.51 & 0.32 & 47.5 & 0.192 & 0.040 & 0.092 & 100 \\
\hline 07-SB4-1402 (B) & 07-3008 & 9.94 & 8.44 & 0.052 & 1.18 & 0.00 & 0.057 & 10.9 & 0.216 & 4.67 & 0.938 & 2.78 & 12.2 & 0.52 & 0.31 & 47.9 & 0.192 & 0.030 & 0.090 & 100 \\
\hline 07-SB4-1404 (A) & 07-3009 & 10.1 & 8.44 & 0.050 & 1.17 & 0.00 & 0.057 & 10.5 & 0.234 & 4.67 & 0.956 & 2.81 & 12.4 & 0.51 & 0.31 & 47.7 & 0.232 & 0.030 & 0.088 & 100 \\
\hline 07-SB4-1404 (B) & 07-3009 & 10.1 & 8.37 & 0.050 & 1.16 & 0.00 & 0.064 & 10.7 & 0.248 & 4.64 & 0.989 & 2.78 & 12.5 & 0.52 & 0.31 & 47.1 & 0.235 & 0.031 & 0.090 & 100 \\
\hline anions $(\mathrm{mg} / \mathrm{L})$ & & $\underline{F}$ & $\mathrm{NO2}$ & $\underline{\mathrm{NO} 3}$ & $\underline{\mathrm{HCO} 2}$ & $\underline{\mathrm{SO} 4}$ & PO4 & $\underline{\mathrm{Cl}}$ & $\underline{\mathrm{C} 2 \mathrm{O} 4}$ & & & & & & & & & & & \\
\hline 07-SB4-1402(A) & 07-3008 & $<100$ & $\overline{<100}$ & $\overline{20800}$ & $\overline{54400}$ & $\overline{1060}$ & $<100$ & 207 & $<100$ & & & & & & & & & & & \\
\hline 07-SB4-1402 (B) & 07-3008 & $<100$ & $<100$ & 20200 & 53700 & 1050 & $<100$ & 193 & $<100$ & & & & & & & & & & & \\
\hline 07-SB4-1404 (A) & 07-3009 & $<100$ & $<100$ & 18300 & 49600 & 1180 & $<100$ & 165 & $<100$ & & & & & & & & & & & \\
\hline 07-SB4-1404 (B) & 07-3009 & $<100$ & $<100$ & 18500 & 48500 & 1130 & $<100$ & 160 & $<100$ & & & & & & & & & & & \\
\hline
\end{tabular}

Weight \% Solids Calculations

Empty ;rucible Wt Crucible Wt +

InsolubleCruc Wt+ Wt \%

\begin{tabular}{|c|c|c|c|c|c|c|c|c|c|c|}
\hline Sample & & rucible wt & Vet Sample & Dry wt & Tot Solids & Wet Wt & Dry Wt & Solids & Calcined & Calcined \\
\hline 07-SB4-1402 (A) & $07-3008$ & 43.4945 & 49.0971 & 46.357 & $51.1 \%$ & 5.6026 & 2.863 & $40.6 \%$ & 45.8693 & $42.4 \%$ \\
\hline 07-SB4-1402 (B) & $07-3008$ & 42.3819 & 47.9026 & 45.2020 & $51.1 \%$ & 5.5207 & 2.820 & $40.5 \%$ & 44.7181 & $42.3 \%$ \\
\hline 07-SB4-1404 (A) & 07-3009 & 42.9540 & 48.6131 & 45.7434 & $49.3 \%$ & 5.6591 & 2.789 & $39.0 \%$ & 45.2718 & $41.0 \%$ \\
\hline 07-SB4-1404 (B) & 07-3009 & 44.0719 & 49.6030 & 46.7997 & $49.3 \%$ & 5.5311 & 2.728 & $39.2 \%$ & 46.3450 & $41.1 \%$ \\
\hline
\end{tabular}




\section{Table A-4. Analyses of SB4/Frit 418 and SB/Frit 510 SMRF Test Glass Pour Samples}

\begin{tabular}{|c|c|c|c|c|c|c|c|c|c|c|c|c|c|c|c|c|c|c|c|c|c|c|c|c|c|c|}
\hline $\begin{array}{c}\text { Sample ID } \\
\text { elemental wt } \%\end{array}$ & Lab ID & Al $>$ & & & & & & & & & & & & & & & & & & & & & & & & \\
\hline $\begin{array}{l}\text { elemental wt } \% \\
\text { SMRF-0230 (A) }\end{array}$ & $\begin{array}{l}07-2640 \\
\end{array}$ & $\frac{\underline{1}}{5.30}$ & $\frac{\underline{9}}{2.64}$ & $\frac{\underline{0 .}}{0.051}$ & $\begin{array}{r}\text { Ca } \\
0.729 \\
\end{array}$ & $\frac{\mathrm{Cr}}{0.049}$ & $\frac{\mathrm{Cu}}{0.021}$ & $\frac{\mathrm{re}}{7.34}$ & $<\frac{G d}{<0.010}$ & $\frac{K}{0.171}$ & $\frac{\underline{L}}{2.29}$ & $\frac{\mathrm{Mg}}{0.584}$ & $\frac{\mathrm{Mn}}{1.66}$ & $\frac{\mathrm{Na}}{9.0}$ & $\frac{\mathrm{N} 1}{0.414}$ & $\frac{\underline{p}}{<0.100}$ & $\frac{\mathrm{pb}}{0.014}$ & $\frac{p d}{<0.010}$ & $<\frac{\mathrm{Rh}}{<0.010}$ & $\frac{\mathrm{Ru}}{0.024}$ & $\frac{\mathrm{S}}{0.147}$ & $\frac{31}{22.7}$ & $\begin{array}{c}\text { II } \\
0.089 \\
\end{array}$ & $\underline{\underline{1}} 0.039$ & $\underline{\underline{1}} .073$ & \\
\hline SMRF-0230 (B) & $07-2640$ & 5.31 & 2.60 & 0.052 & 0.727 & 0.050 & 0.022 & 7.13 & $<0.010$ & 0.158 & 2.31 & 0.603 & 1.61 & 9.0 & 0.451 & $<0.100$ & 0.015 & $<0.010$ & $<0.010$ & 0.022 & 0.150 & 22.7 & 0.093 & 0.041 & 0.073 & \\
\hline SMRF-0231 (A) & \begin{tabular}{|l|l|}
$07-2641$ \\
$07-2641$
\end{tabular} & 5.49 & 1.79 & 0.032 & 0.807 & 0.042 & 0.022 & $\begin{array}{l}7.60 \\
777\end{array}$ & $<0.010$ & 0.122 & 2.22 & 0.609 & 1.71 & 9.2 & 0.404 & $<0.100$ & $<0.010$ & $<0.010$ & $<0.010$ & 0.020 & 0.134 & 23.3 & 0.074 & 0.024 & 0.096 & \\
\hline SMRF-0231 (B) & $07-2641$ & 5.58 & 1.78 & 0.033 & 0.809 & 0.043 & 0.020 & 7.77 & $<0.010$ & 0.116 & 2.24 & 0.627 & $\begin{array}{l}1.70 \\
1.77\end{array}$ & 9.1 & 0.431 & $<0.100$ & $<0.010$ & $<0.010$ & $<0.010$ & 0.022 & 0.137 & 23.6 & 0.076 & 0.025 & 0.099 & \\
\hline $\begin{array}{l}\text { SMRF-0232(A) } \\
\text { SMRF-0232 (B) }\end{array}$ & $\begin{array}{l}07-2642 \\
07-2642\end{array}$ & 5.52 & $\frac{1.74}{1.73}$ & $\begin{array}{l}0.033 \\
0.033\end{array}$ & $\begin{array}{l}0.813 \\
0.825\end{array}$ & $\begin{array}{l}0.055 \\
0.053\end{array}$ & 0.024 & $\begin{array}{l}7.81 \\
7.70\end{array}$ & $\begin{array}{l}<0.010 \\
<0.010\end{array}$ & $\frac{0.115}{0.127}$ & $\frac{2.23}{2.25}$ & $\frac{0.635}{0.618}$ & $\begin{array}{l}1.77 \\
1.74\end{array}$ & 9.1 & 0.4522 & $\begin{array}{l}<0.100 \\
<<.100\end{array}$ & $\begin{array}{l}<<.010 \\
<0.010\end{array}$ & $\begin{array}{l}<0.010 \\
<0.010\end{array}$ & $\begin{array}{l}<<.010 \\
<0.010\end{array}$ & $\frac{0.020}{0.021}$ & $\begin{array}{l}0.138 \\
0.139\end{array}$ & $\frac{23.4}{23.6}$ & \begin{tabular}{|l}
0.070 \\
0.068
\end{tabular} & 0.026 & \begin{tabular}{|l}
0.103 \\
0.101
\end{tabular} & \\
\hline & & & & & & & & & & & & & & & & & & & & & & & & & & \\
\hline$\frac{\text { oxide wt } \%}{\text { SMRF-0230 (A) }}$ & $\begin{array}{l}07-2640 \\
\end{array}$ & $\frac{\mathrm{A} 12 \mathrm{O} 3}{10.0}$ & $\frac{\mathrm{B} 203}{8.50}$ & $\frac{\mathrm{BaO}}{0.057}$ & $\frac{\mathrm{CaO}}{1.02}$ & $\frac{\mathrm{C}^{2} \mathrm{OO} 3}{0.072}$ & $\frac{\mathrm{CuO}}{0.026}$ & $\frac{\mathrm{Fe}_{2} \mathrm{OO} 3}{10.5}$ & $\frac{\mathrm{GdaO} 23}{0.0}$ & $\frac{\mathrm{K} 2 \mathrm{O}}{0.205}$ & $\frac{\underline{\mathrm{i}} 20}{4.92}$ & $\frac{\mathrm{MgO}}{0.969}$ & $\frac{\mathrm{MnO} 2}{2.62}$ & $\frac{\mathrm{Na2O}}{12.1}$ & $\frac{\mathrm{NiO}}{0.526}$ & $\frac{\mathrm{P} 2 \mathrm{O} 5}{0.00}$ & $\frac{\underline{P b O}}{0.015}$ & $\frac{\mathrm{PdO}}{0.000}$ & $\frac{\text { RhO2 }}{0.000}$ & $\frac{\mathrm{RuO2}}{0.032}$ & $\frac{\mathrm{SO} 4}{0.441}$ & $\frac{S \mathrm{SiO} 2}{48.6}$ & $\frac{\mathrm{TiO} 2}{0.149}$ & $\frac{\underline{\mathrm{ZnO}}}{0.048}$ & $\begin{array}{c}\text { Zro2 } \\
0.099 \\
\end{array}$ & $\begin{array}{l}\text { Totals } \\
101 \\
\end{array}$ \\
\hline SMRF-0230 (B) & \begin{tabular}{|l|l|}
$07-2640$ \\
\end{tabular} & 10.0 & 8.37 & 0.058 & 1.02 & 0.073 & 0.028 & 10.2 & 0.0 & 0.190 & 4.97 & 1.00 & 2.54 & 12.1 & 0.573 & 0.00 & 0.016 & 0.000 & 0.000 & 0.029 & 0.450 & 48.6 & 0.155 & 0.051 & 0.099 & 100 \\
\hline SMRF-0231 (A) & \begin{tabular}{|l|l|}
$07-2641$ \\
\end{tabular} & 10.4 & 5.76 & 0.036 & 1.13 & 0.061 & 0.028 & 10.9 & 0.0 & 0.146 & 4.77 & 1.01 & 2.70 & 12.4 & 0.513 & 0.00 & 0.000 & 0.000 & 0.000 & 0.026 & 0.402 & 49.9 & 0.124 & 0.030 & 0.130 & 10 \\
\hline SMRF-0231 (B) & \begin{tabular}{|l|l|}
$07-2641$ \\
\end{tabular} & 10.5 & 5.73 & 0.037 & 1.13 & 0.063 & 0.025 & 11.1 & 0.0 & 0.139 & 4.82 & 1.04 & 2.69 & 12.3 & 0.547 & 0.00 & 0.000 & 0.000 & 0.000 & 0.029 & 0.411 & 50.5 & 0.127 & 0.031 & 0.134 & 10 \\
\hline SMRF-0232 (A) & \begin{tabular}{|l|l|l|l|}
$07-2642$ \\
\end{tabular} & 10.4 & 5.60 & 0.037 & 1.14 & 0.080 & 0.030 & 11.2 & 0.0 & 0.138 & 4.79 & 1.05 & 2.80 & 12.3 & 0.574 & 0.00 & 0.000 & 0.000 & 0.000 & 0.026 & 0.414 & 50.1 & 0.117 & 0.032 & 0.139 & 10 \\
\hline SMRF-0232 (B) & \begin{tabular}{|l|l|l|l|l}
$07-2642$ \\
\end{tabular} & 10.5 & 5.57 & 0.037 & 1.16 & 0.077 & 0.033 & 11.0 & 0.0 & 0.152 & 4.84 & 1.03 & 2.75 & 12.4 & 0.521 & 0.00 & 0.000 & 0.000 & 0.000 & 0.028 & 0.417 & 50.5 & 0.114 & 0.031 & 0.136 & 101 \\
\hline & & & & & & & & & & & & & & & & & & & & & & & & & & \\
\hline Sample & Lab ID & $\mathrm{Fe}(2+)$ & $\mathrm{Fe}(3+)$ & Fe(total & $\frac{\mathrm{Fe}(2+1)}{\mathrm{Fe}(3+)}$ & $\frac{1}{\mathrm{Fe} \text { (total) }}$ & & & & & & & & & & & & & & & & & & & & \\
\hline EA & & 0.051 & 0.204 & 0.255 & 0.250 & 0.200 & & & & & & & & & & & & & & & & & & & & \\
\hline SMRF-0230 (A) & $07-2640$ & 0.089 & 0.355 & 0.444 & 0.251 & 0.200 & & & & & & & & & & & & & & & & & & & & \\
\hline SMRF-0230 (B) & $07-2640$ & 0.089 & 0.355 & 0.444 & 0.251 & 0.200 & & & & & & & & & & & & & & & & & & & & \\
\hline SMRF-0231 (A) & $07-2641$ & 0.090 & 0.327 & 0.417 & 0.275 & & & & & & & & & & & & & & & & & & & & & \\
\hline SMRF-0231 (B) & $07-2641$ & 0.091 & 0.330 & 0.421 & 0.276 & 0.216 & & & & & & & & & & & & & & & & & & & & \\
\hline & & & & & & & & & & & & & & & & & & & & & & & & & & \\
\hline SMRF & 07-2642 & .1110 & 0.377 & 0.487 & 0.292 & 0.226 & & & & & & & & & & & & & & & & & & & & \\
\hline SMRF-0232 (B) & 07-2642 & 0.109 & 0.379 & 0.488 & 0.288 & 0.223 & & & & & & & & & & & & & & & & & & & & \\
\hline
\end{tabular}

Notes: SMRF-0230 is last pour glass sample (7/10/07@1740 hours) for SB4/Frit 510 test SMRF-0231 is last pour glass sample (7/12/07@1255 hours) for SB4/Frit 418 test SMRF-0232 is drain glass sample after SB4/Frit 418 test 
This page intentionally left blank. 


\section{Distribution:}

J. E. Marra, 773-A

R. E. Edwards, 773-A

D. A. Crowley, 999-W

C. C. Herman, 999-W

A. B. Barnes, 999-W

D. B. Burns, 786-5A

M. E. Smith, 999-W

D. H. Miller, 999-W

T. M. Jones, 999-W

C. J. Bannochie, 773-42A

B. R. Pickenheim, 999-W

C. M. Jantzen, 773-A

D. K. Peeler, 999-W

M. E. Stone, 999-W

D. P. Lambert, 999-W

A. S. Choi, 773-42A

K. M. Fox, 999-W

J. D. Newell, 999-W

F. C. Raszewski, 999-W

A. L. Youchak, 999-W

S. D. Burke, 704-S

J. E. Occhipinti, 704-S

J. F. Iaukea, 704-30S

J. W. Ray, 704-S

R. T. McNew, 704-27S

B. A. Davis, 704-27S

D. C. Iverson, 704-30S

R. J. O'Driscoll, 704-30S

J. Stuberfield, Jr., 766-H

P. J. Hill, 766-H

B. A. Hamm, 766-H

J. M. Gillam, 766-H

H. B. Shah, 766-H 